\title{
Analisis Pengaruh Penggunaan E-Learning dengan Google Classroom dan Disiplin Belajar terhadap Motivasi Belajar Mahasiswa Brothers and Sisters House Kota Surabaya pada Masa Pandemi Covid-19
}

\author{
Alfred Liubana*, Durinda Puspasari \\ Program Studi Pendidikan Administrasi Perkantoran, Fakultas Ekonomi \\ Universitas Negeri Surabaya \\ *Corresponding Author. Email: alfred.17080314099@mhs.unesa.ac.id
}

\begin{abstract}
The purpose of this study was to analyze the effect of using e-learning with google classroom and learning discipline on the learning motivation of the students of brothers and sisters house in Surabaya city during the Covid-19 pandemic. This research is quantitative. This study used proportional random sampling using the Slovin formula so that the sample amounted to 90 students. The data techniques used were questionnaires and interviews. Testing instruments in this study consisted of validity testing and reliability testing. This study's data analysis techniques are: 1) classical assumption test consisting of normality test, multicollinearity test, heteroscedasticity test; 2) hypothesis testing using multiple linear regression. The results of this study indicate that the use of e-learning with google classroom and learning discipline simultaneously have a significant influence on the learning motivation of the students of brothers and sisters house in Surabaya city during the Covid-19 pandemic.
\end{abstract}

\begin{abstract}
Abstrak: Tujuan dari penelitian ini adalah untuk menganalisis pengaruh penggunaan e-learning dengan google classroom dan disiplin belajar terhadap motivasi belajar mahasiswa brothers and sisters house kota Surabaya pada masa pandemi Covid-19. Penelitian ini merupakan penelitian kuantitatif. Penelitian ini menggunakan proportional random sampling dengan menggunakan rumus Slovin sehingga sampel berjumlah 90 mahasiswa. Uji coba instrumen dalam penelitian ini terdiri dari uji validitas dan uji reliabilitas. Teknik analisis data yang digunakan dalam penelitian ini yaitu: 1) uji asumsi klasik yang terdiri dari uji normalitas, uji multikoliniearitas, dan uji heteroskedastisitas; 2) uji hipotesis menggunakan regresi linier berganda. Hasil penelitian ini menunjukkan bahwa terdapat pengaruh signifikan penggunaan e-learning dengan google classroom dan disiplin belajar terhadap motivasi belajar mahasiswa brothers and sisters house kota Surabaya pada masa pandemi Covid-19.
\end{abstract}

\section{Article History}

Received: 28-02-2021

Revised: 05-04-2021

Accepted: 20-04-2021

Published: 07-06-2021

\section{Key Words: \\ E-learning, Google \\ Classroom, Learning \\ Discipline, Learning \\ Motivation.}

\section{Sejarah Artikel \\ Diterima: 28-02-2021 \\ Direvisi: 05-04-2021 \\ Disetujui: 20-04-2021 \\ Diterbitkan: 07-06-2021 \\ Kata Kunci: \\ E-learning, \\ Google Classroom, \\ Disiplin Belajar, \\ Motivasi Belajar.}

How to Cite: Liubana, A., \& Puspasari, D. (2021). Analisis Pengaruh Penggunaan E-Learning dengan Google Classroom dan Disiplin Belajar terhadap Motivasi Belajar Mahasiswa Brothers and Sisters House Kota Surabaya pada Masa Pandemi Covid-19. Jurnal Kependidikan: Jurnal Hasil Penelitian dan Kajian Kepustakaan di Bidang Pendidikan, Pengajaran dan Pembelajaran, 7(2), 417-427. doi:https://doi.org/10.33394/jk.v7i2.3599

https://doi.org/10.33394/jk.v7i2.3599

This is an open-access article under the CC-BY-SA License.

\section{Pendahuluan}

Saat ini dunia sedang dilanda dengan adanya kasus Covid-19, bahkan negara-negara yang terkena dampak ini melakukan lockdown demi meminimalisirkan penyebaran Covid-19. Negara yang terkena dampak ini salah satunya yaitu Indonesia. Pemerintah Indonesia memberikan edaran dan mengkonfirmasikan adanya kasus Covid-19 pertama kalinya yaitu pada tanggal 02 Maret 2020 (Wahyono, 2020). Sehingga pemerintah melakukan langkah tegas untuk memutus rantai penyebaran Covid-19. Adanya Covid-19 menimbulkan pengaruh yang tidak sehat pada berbagai sektor yang ada salah satunya adalah pada bidang pendidikan, 
di mana pembelajaran pada mulanya dilakukan secara langsung tetapi saat ini pembelajaran harus dilaksanakan secara daring atau online. Oleh karena itu, edaran dari Siaran Pers Nomor: 137/sipres/A6/VI/2020 pada 15/07/2020 tentang penyelenggaraan pembelajaran yang akan dilaksanakan pada tahun akademik baru terkhususnya di masa pandemi: daerah berstatuskan kuning, oranye dan merah maka tidak melaksanakan kegiatan belajar secara langsung (Kemendikbud, 2020) serta diikuti dengan pemberitahuan atau himbauan yang diperoleh dari masing-masing pemerintah di perguruan tinggi tersebut berada.

Adanya peraturan yang dikeluarkan tersebut, maka pembelajaran yang biasanya dilakukan secara tatap muka dirubah untuk melakukan aktivitas pembelajaran dari rumah masing-masing yang dikenal dengan stay at home, yang di Indonesia sendiri diberlakukan secara bersamaan pada bulan Maret 2020. Oleh karena itu, setiap instansi bisa memanfaatkan teknologi untuk melakukan pembelajaran secara daring atau yang dikenal sebagai $e$-learning. E-learning dapat dikatakan suatu media pembelajaran dikarenakan memanfaatkan internet, yang bertujuan untuk memberikan solusi dan dapat meningkatkan pengetahuan dan keterampilan pada seseorang (Sabran \& Sabara, 2019). Oleh karena itu, dengan adanya $e$ learning dapat membantu untuk menyampaikan pembelajaran yang tidak diajarkan secara langsung oleh tenaga pendidik.

Media yang biasanya dimanfaatkan dengan adanya e-learning agar mendukung dan melakukan proses pembelajaran adalah google classroom. Google classroom bisa digunakan kapan dan dimanapun dengan adanya bantuan komputer atau smartphone. Google classroom adalah suatu layanan pendidikan yang bertujuan untuk menyederhanakan, membuat, mendistribusikan dan bahkan memberikan penilaian terhadap tugas tanpa adanya tatap muka secara langsung (Fauzan \& Arifin, 2019). Google classroom merupakan aplikasi dimana pengembangannya oleh google dengan maksud dan tujuan membantu dalam proses pembelajaran bahkan sebagai komunikasi antara dosen dan mahasiswa diluar jam perkuliahan. Hal ini didukung oleh peneliti Sabran \& Sabara (2019) yang mana hasil penelitiannya bahwa dalam melakukan rencana pembelajaran dengan bantuan google classroom cukup efektif $77,57 \%$; materi yang dibuat $75,14 \%$; materi yang disampaikan oleh dosen $75 \%$; interaksi antara dosen dan mahasiswa 66,10\%; melakukan proses evaluasi belajar 69,01\%; dan pelaksanaan pembelajaran dengan google classroom mempunyai kriteria cukup efektif sebesar $77,27 \%$. Terdapat pula hasil penelitian yang mendukung mengenai penggunaan google classroom oleh Albashtawi \& Al Bataineh (2020) yang menunjukkan bahwa sebelum menggunakan google classroom hasil nilai rata-rata pretest adalah 53,60\% untuk membaca dan menulis, dan setelah menggunakan google classroom maka hasil posttestnya adalah $56,77 \%$ untuk membaca dan menulis. Penelitian yang serupa juga dilakukan oleh Nirfayanti \& Nurbaeti (2019) yang membahas tentang google classroom juga memberikan kesimpulan adanya pengaruh motivasi belajar mahasiswa ketika diterapkannya google classroom dimana dapat dilihat dari nilai pada t-hitung $=43,116$ dan sig. $0,000<0,05$ bahkan berada pada kategori sangat baik yaitu sebesar $83,72 \%$. Adanya google classroom ini diharapkan dapat membantu dan memudahkan setiap pengguna baik itu mahasiswa maupun dosen dalam melaksanakan kegiatan belajar dari rumah di masa pandemi. Dikarenakan dengan adanya google classroom mahasiswa dan dosen dapat memberikan materi, mahasiswa bisa mengumpulkan tugasnya, mengedarkan, memberikan nilai dimanapun tanpa dibatasi dengan waktu (Nirfayanti \& Nurbaeti, 2019).

Disiplin belajar adalah salah satu faktor penting di dalam pembelajaran. Sikap disiplin belajar dibutuhkan oleh setiap orang terutama bagi seorang mahasiswa dimana harus disiplin untuk menyelesaikan tugas, ketaatan dalam pembelajaran bahkan untuk mengikuti setiap perkuliahan yang ada sehingga tujuan pembelajaran yang telah ditentukan bisa tercapai 
dengan baik dan benar (Dwi, Muhsin, \& Rozi, 2019). Dalam melakukan suatu pembelajaran, mahasiswa perlu adanya suatu kesadaran sendiri untuk disiplin belajar, jika tidak maka disiplin belajar tersebut tidak akan bertahan lama dalam diri mahasiswa tersebut. Oleh karena itu, disiplin belajar seorang mahasiswa dapat dibiasakan dan ditumbuhkan melalui penanaman suatu kebiasaan yang berhubungan dengan disiplin dimana bisa dimulai dari lingkungan keluarga. Hal ini didukung oleh penelitian dari Mulyany (2014) yang membahas disiplin belajar yang menyatakan bahwa disiplin belajar mempengaruhi motivasi belajar dimana dapat dilihat berdasarkan indeks variabel disiplin belajar diperoleh skor sebesar $76,52 \%$ termasuk dalam kriteria tinggi yang terletak pada interval 70.01-100. Penelitian Yussi, Syaad, \& Purnomo (2016) menyatakan pula bahwa disiplin memberikan kontribusi yang signifikansi terhadap motivasi belajar hal ini juga akan memberikan suatu dampak kepada hasil belajar dimana nilai perhitungan disiplin belajar sebesar 43,2\%. Menurut Susanto, Farihen, \& Iswan (2020) dalam penelitiannya juga membahas disiplin belajar dimana hasil penelitiannya terbukti terdapat pengaruh signifikansi disiplin belajar terhadap prestasi belajar dilihat dari nilai sig. $0,001<0,05$ dan Fhitung $=37,61$. Oleh karena itu, dalam melakukan pembelajaran yang ada maka seorang mahasiswa perlu adanya disiplin belajar agar mahasiswa mempunyai motivasi yang kuat untuk belajar.

TRUST (The Real Ultimate Student) adalah salah satu lembaga pelayanan mahasiswa ekstra-kampus yang berfokus pada pendidikan, mental dan spiritual yang telah berdiri mulai tahun 1996. Brothers and Sister House adalah salah satu bagian dari TRUST yang ada di Indonesia dan menyebar pada kota-kota besar dan salah satunya di kota Surabaya. Brothers and Sisters House adalah asrama yang ada di sekitar kampus dimana mahasiswa melaksanakan kuliah dengan tujuan untuk mempermudah mahasiswa dan membantu dalam tiga aspek penting yaitu pendidikan, mental dan spiritual. Aspek pendidikan, mahasiswa disediakan fasilitas berupa ruang belajar, wifi, workshop study, kelompok belajar, bimbingan pembelajaran, membagikan tips dalam pembelajaran bahkan menyediakan kendaraan yang bisa digunakan oleh mahasiswa untuk menunjang perkuliahan. Aspek karakter, mahasiswa diikutsertakan dalam kegiatan youth camp and outing, leadership training dan sport activity. Aspek spiritual, mahasiswa wajib mengikuti setiap kegiatan-kegiatan seperti kelompok keagamaan dan study, youth conference, spiritual counseling dan retreat. Oleh karena itu, dengan ketiga aspek ini diharapkan mahasiswa bisa seimbang dalam kehidupannya seharihari (Trust, 2020).

Berdasarkan studi pendahuluan yang dilakukan di Brothers and Sisters House kota Surabaya menunjukkan bahwa $48 \%$ mahasiswa memilih pembelajaran dengan google classroom dibandingkan dengan yang lainnya, 64\% tidak mengalami kesulitan dalam mengakses google classroom, bahkan dengan adanya google classroom mahasiswa semakin disiplin dalam mengerjakan tugas. Oleh sebab itu pernyataan ini pun didukung oleh Pradana \& Harimurti (2017) yang menjelaskan bahwa google classroom sangat direkomendasikan dalam melaksanakan pembelajaran dikarenakan sebagai media yang dapat membantu mahasiswa dan dosen dalam melaksanakan pembelajaran. Bahkan melatih mahasiswa untuk lebih disiplin dalam mengerjakan tugas. Namun, berdasarkan hasil wawancara dengan beberapa mahasiswa Brothers and Sisters House kota Surabaya mengatakan bahwa dengan berjalannya waktu pada masa pandemi Covid-19 ini, mahasiswa merasa jenuh dengan pembelajaran yang dilakukan di google classroom dan cenderung mulai kurang disiplin dalam mengerjakan tugas yang ada dibandingkan sebelumnya, sehingga dapat dikatakan bahwa motivasi belajar mahasiswa pada masa pandemi Covid-19 ini mulai mengalami penurunan. 
Adapun penelitian ini memiliki tujuan untuk menganalisis: 1) pengaruh penggunaan e-learning dengan google classroom terhadap motivasi belajar mahasiswa brothers and sisters house kota Surabaya pada masa pandemi Covid-19; 2) pengaruh disiplin belajar terhadap motivasi belajar mahasiswa brothers and sisters house kota Surabaya pada masa pandemi Covid-19; 3) pengaruh penggunaan e-learning dengan google classroom dan disiplin belajar terhadap motivasi belajar mahasiswa brothers and sisters house kota Surabaya pada masa pandemi Covid-19.

\section{Metode Penelitian}

Penelitian ini merupakan penelitian kuantitatif. Menurut Sugiyono (2019), penelitian kuantitatif merupakan jenis penelitian yang berdasarkan pada filsafat positivisme, dan ilmiah dikarenakan penelitian tersebut konkrit, obyektif, dapat diukur, rasional dan sistematis yang bertujuan menguji hipotesis dari penelitian. Model konseptual penelitian ini dapat dilihat pada gambar berikut ini:

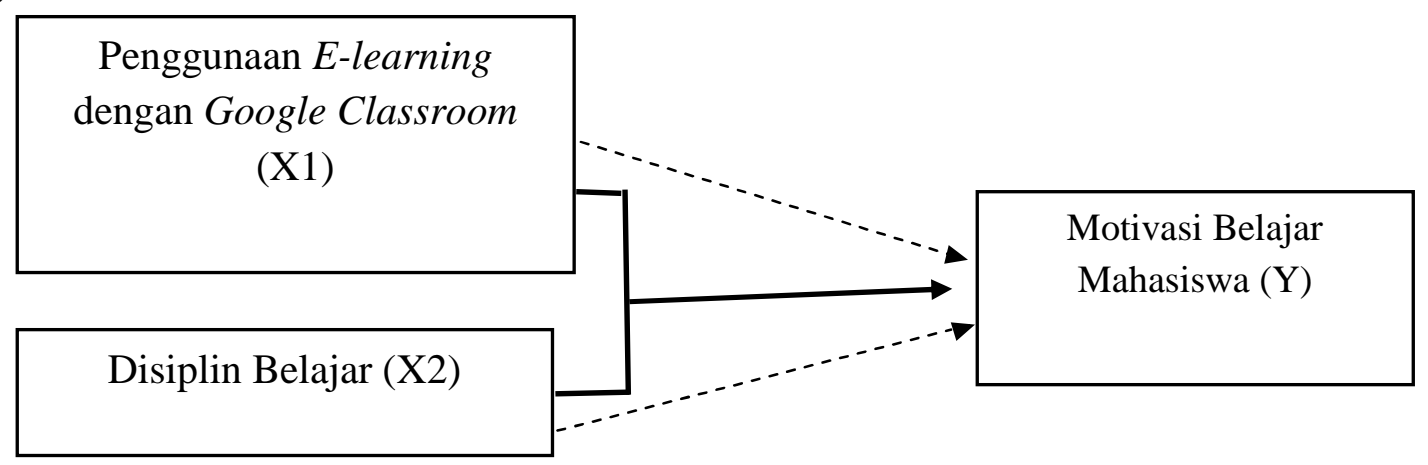

Keterangan:

\section{Gambar 1. Model Konseptual Penelitian}

Hubungan variabel secara simultan

- - - - - - Hubungan variabel secara parsial

Teknik pengumpulan data berupa penyebaran angket menggunakan skala likert dan wawancara untuk studi pendahuluan dengan menggunakan pedoman wawancara tidak terstruktur. Sedangkan populasi dalam penelitian ini adalah mahasiswa brothers and sisters house kota Surabaya yang berjumlah 115 orang. Dalam penelitian ini untuk mengambil sampel yang dibutuhkan maka peneliti menggunakan proportional random sampling. Perhitungan sampel dengan menggunakan rumus Slovin dengan tujuan untuk mengetahui jumlah sampel yang dibutuhkan sebagai berikut:

$$
n=\frac{N}{1+N(e)^{2}}
$$

Sumber: Sugiyono (2019)

Keterangan:

n : banyaknya sampel yang dibutuhkan oleh peneliti

$\mathrm{N} \quad$ : banyaknya populasi

e : sampling error

Jadi kesimpulan untuk total sampel yang dibutuhkan adalah berjumlah 90 orang mahasiswa. Uji coba instrumen yang terdapat dalam penelitian ini adalah; 1) uji validitas, yaitu instrumen yang dipakai dalam mengukur data valid atau tidak valid. Syarat minimum yang terdapat dalam uji validitas adalah rhitung > rtabel maka akan dikatakan valid;2) uji reliabilitas, yaitu instrumen untuk mengukur obyek dalam penelitian dalam beberapa kali pun dapat memberikan data yang sama tanpa adanya perubahan apapun. Menurut Murni \& Pratiwi 
(2020) uji reliabilitas digunakan untuk tujuan mengetahui kuesioner penelitian benar dipercaya sebagai alat pengumpulan data yang reliabel. Metode yang digunakan adalah melihat Cronbach's Alpha. Apabila Cronbach's Alpha > 0,60 maka akan disimpulkan bahwa data tersebut reliabel (Sugiyono, 2019).

Teknik analisis data berupa; 1) uji asumsi klasik yaitu a) uji normalitas, mempunyai suatu tujuan untuk menguji dan mengetahui apakah di dalam suatu variabel bebas dan variabel terikat ataupun keduanya memiliki data yang berdistribusi normal atau tidak berdistribusi normal (Novianty, 2019). Menurut Sujianto (2009), dalam menentukan kriteria jika mempunyai nilai sig. > 0,05 data tersebut adalah normal, namun nilai sig. < 0,05 dapat dikatakan data tersebut tidak normal. Penelitian ini menggunakan P-Plot untuk uji normalitas, b) uji multikolinieritas, adalah pengujian yang dimana ingin mengetahui apakah akan ada variabel bebas atau apakah variabel bebas mempunyai regresi korelasi yang tinggi (Gozali, 2018). Untuk mengetahui uji multikolinearitas maka menggunakan nilai pada VIP setiap variabel bebas, jika nilai VIF $<10$ bisa ditarik kesimpulannya tidak terdapat multikolinearitas, c) uji heteroskedastisitas, mempunyai tujuan untuk mengetahui apakah dalam model regresi terdapat ketidaksamaan varian dari residual satu pengamatan ke pengamatan yang lainnya (Wati \& Muhsin, 2019). Apabila memiliki heteroskedastisitas maka akan ditandai dengan pola yang berbentuk dan teratur pada scatterplot, baik bentuk menyempit, melebar, ataupun bergelombang. Jika pada scatterplot ditemukan pola yang tidak berbentuk sesuatu dan tidak beraturan, maka dapat dikatakan variabel bebas bersifat homoskedastisitas atau dengan kata lain tidak ditemukannya heteroskedastisitas (Cintya \& Nugraha, 2020); 2) Uji hipotesis menggunakan regresi linear berganda dengan tujuan menganalisis apakah terdapat pengaruh dari dua variabel ataupun lebih variabelnya yaitu variabel independen dan dependen, yaitu pengaruh penggunaan e-learning dengan google classroom $\left(\mathrm{X}_{1}\right)$ dan disiplin belajar $\left(\mathrm{X}_{2}\right)$ terhadap motivasi belajar mahasiswa brothers and sisters house kota Surabaya pada era pandemi covid-19 (Y) baik secara parsial/sendiri atau secara simultan/bersamaan.

\section{Hasil Penelitian dan Pembahasan}

Dari hasil output pengolahan data dengan software IBM SPSS Statistics 25 dapat diketahui bahwa pernyataan angket pada penelitian ini valid dikarenakan nilai r-hitung > nilai r-tabel, dimana hasil pengujian pernyataan validitas dilakukan pada 42 instrumen pernyataan yaitu; 10 pernyataan yang berhubungan dengan penggunaan e-learning dengan google classroom (X1), 13 item pernyataan yang berhubungan dengan disiplin belajar (X2), dan 19 item pernyataan yang berhubungan dengan motivasi belajar mahasiswa (Y).

Dari hasil output pengolahan data dengan software IBM SPSS Statistics 25 dapat diketahui bahwa instrumen pernyataan angket dinyatakan reliabel dengan kriteria sangat tinggi dimana dapat dilihat pada nilai Cronbach's Alpha penggunaan e-learning dengan google classroom 0,872>0,6, disiplin belajar 0,839>0,6 dan motivasi belajar mahasiswa $0,912>0,6$.

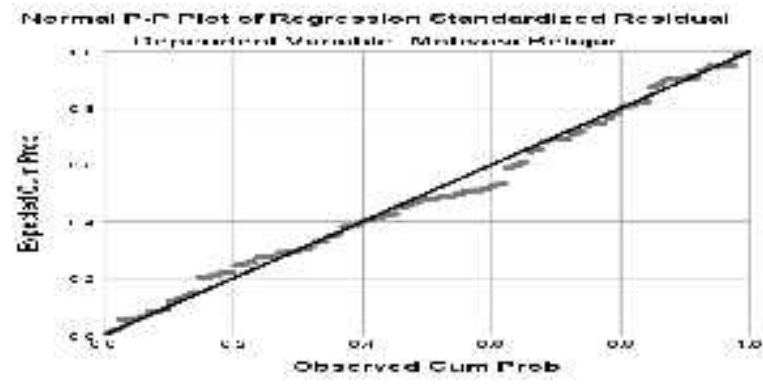

Gambar 2. Hasil Uji Normalitas

Jurnal Kependidikan Vol. 7. No. 2 : Juni 2021 
Berdasarkan hasil output Tests of Normality maka dapat dinyatakan data berdistribusi normal dikarenakan pada gambar p-p plot titik-titik berdekatan pada garis diagonalnya.

Tabel 1. Uji Multikolinearitas

\begin{tabular}{lll}
\hline Variabel & Tolerance & VIF \\
\hline $\begin{array}{l}\text { Penggunaan e-learning dengan } \\
\text { google classroom }\end{array}$ &, 689 & 1,452 \\
Disiplin belajar &, 689 & 1,452 \\
\hline
\end{tabular}

Dari hasil uji multikolinearitas diketahui dari perhitungan tidak terdapat multikolinearitas, dimana dibuktikan dengan hasil dari Tolerance 0,689>0,10 sedangkan nilai VIF $1,452<10$. Oleh karena itu, ditarik satu kesimpulan bahwa tidak terdapat gejala yang yang menunjukan multikolinearitas dan tidak ada korelasi antar variabel bebas dalam penelitian ini.

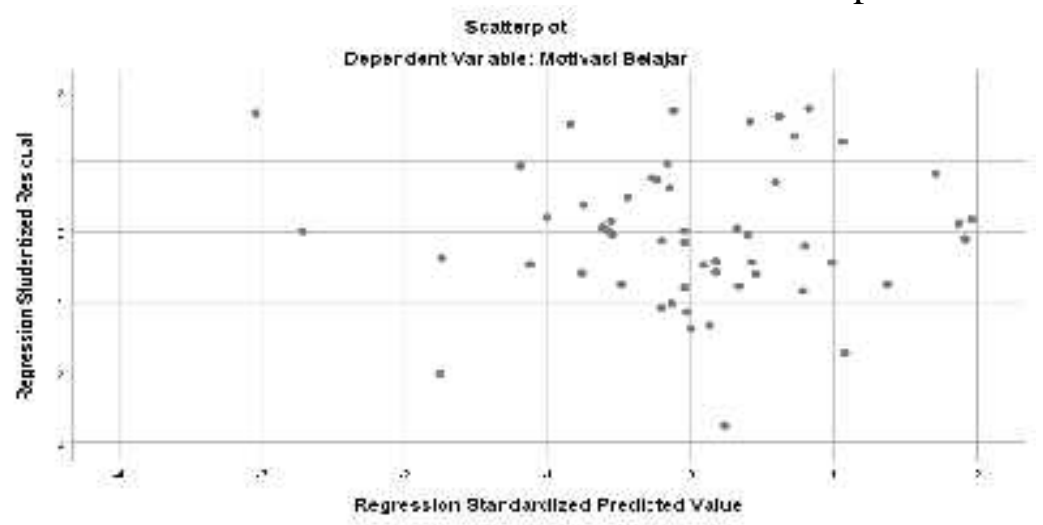

Gambar 3. Hasil Uji Heteroskedastisitas

Dari output gambar 3 hasil uji heteroskedastisitas maka dapat disimpulkan bahwasanya titiktitik pada scatterplot tersebar di sekitar angka 0 bahkan tidak hanya pada satu tempat, oleh sebab itu dapat dikatakan bahwa penelitian yang dilakukan ini tidak terdapat heteroskedastisitas.

Uji hipotesis dalam penelitian ini menggunakan uji regresi linier berganda. Hasil uji regresi linier berganda dapat ditunjukkan sebagai berikut:

Tabel 2. Hasil Uji-t

\begin{tabular}{|c|c|c|c|c|c|}
\hline \multicolumn{6}{|c|}{ Coefficients $^{\mathrm{a}}$} \\
\hline & \multirow[t]{2}{*}{ Model } & \multicolumn{2}{|c|}{$\begin{array}{l}\text { Unstandarized } \\
\text { Coefficents }\end{array}$} & \multirow[t]{2}{*}{$\mathrm{t}$} & \multirow[t]{2}{*}{ Sig. } \\
\hline & & B & Std. Error & & \\
\hline \multirow[t]{3}{*}{1} & (Constant) & 8,937 & 5,816 & 1,537 & , 128 \\
\hline & $\begin{array}{l}\text { Penggunaan e-learning } \\
\text { dengan google classroom }\end{array}$ & ,322 &, 138 & 2,343 & 021 \\
\hline & Disiplin belajar & 1,012 & ,130 & 7,813 & ,000 \\
\hline
\end{tabular}

a. Dependet Variabel: Motivasi belajar

Berdasarkan output dari tabel 2. maka diketahui persamaan regresi linear berganda adalah sebagai berikut:

$\mathrm{Y}=8,937+0,322 \mathrm{X}_{1}+1,012 \mathrm{X}_{2}$

Dari hasil uji-t diketahui penggunaan e-learning dengan google classroom $\left(\mathrm{X}_{1}\right)$ terdapat pengaruh yang signifikan terhadap motivasi belajar mahasiswa brothers and sisters house kota Surabaya pada masa pandemi Covid-19. Terbukti dari dari nilai pada t-hitung 2,343> t-tabel 1,989 dan nilai sig. 0,021 < 0,05. Ini pun didukung oleh peneliti Nirfayanti \& Nurbaeti (2019) dalam penelitiannya memberikan kesimpulan bahwa ada pengaruh signifikansi motivasi belajar mahasiswa ketika diterapkannya pembelajaran di google 
classroom dimana dapat dilihat dari nilai t-hitung sebesar $=43,11$ dan nilai sig. $0,000<0,05$ dan nilai skor pada rata-rata hasil belajar mahasiswa sebesar 83,72\% pada kategori sangat baik; Rikizaputra \& Sulastri (2020) yang menyimpulkan bahwasannya ada pengaruh yang signifikan e-learning dengan google classroom terhadap hasil belajar dan motivasi belajar dimana nilai sig. 0,000 < 0,05; Daniati, Ismanto, \& Luhsasi (2020) dalam hasil penelitiannya menunjukkan bahwa dengan adanya penerapan dari google classroom maka terjadinya peningkatan motivasi belajar, dibuktikan dengan peningkatan sebesar 75,53\% manjadi 87,35\% yang dimana ada peningkatan 13,82\%; Sabran \& Sabara (2019) dimana hasil penelitiannya menunjukkan bahwa dalam melakukan rencana pembelajaran dengan bantuan google classroom cukup efektif $77,57 \%$, materi yang dibuat $75,14 \%$, materi yang disampaikan oleh dosen 75\%, interaksi antara dosen dan mahasiswa 66,10\%, melakukan proses evaluasi belajar $69,01 \%$ dan proses belajar dengan google classroom mempunyai kriteria cukup efektif sebesar 77,27\%; Albashtawi \& Al Bataineh (2020) dari hasil penelitiannya menunjukkan bahwa sebelum menggunakan google classroom hasil nilai ratarata pretest adalah 53,60\% untuk membaca dan menulis, dan setelah menggunakan google classroom maka hasil posttestnya adalah $56,77 \%$ untuk membaca dan menulis; Ridwan \& Umam (2020) dalam hasil penelitiannya menyatakan ada pengaruh yang signifikansi motivasi belajar ketika ada penerapan pembelajaran dengan google classroom yang dibuktikan dari nilai t-hitung sebesar 45,116 dan nilai signifikansi $0,000<0,005$, dan hasil skor responden belajar dengan google classroom dengan kategori tinggi sebesar 78,31\% dan kategori sangat baik sebesar 83,72\%; Yulyani (2020) dalam hasil penelitiannya menjelaskan bahwa dengan google classroom maka memberikan pengaruh signifikan terhadap motivasi belajar mahasiswa, dibuktikan dari nilai t-hitung 5,173 > t-tabel 1,9745 dan pada nilai sig. 0,000 < 0,05 .

Dengan demikian dikatakan dalam penggunaan e-learning dengan google classroom dapat diterima dengan baik oleh mahasiswa, dapat memberikan pengaruh terhadap motivasi belajar mahasiswa brothers and sisters house kota Surabaya pada masa pandemi Covid-19. Penggunaan google classroom dapat meningkatkan performa belajar dan dapat membantu mahasiswa dalam proses perkuliahan. Disamping itu google classroom sangat mudah diakses, google classroom dapat digunakan sesuai dengan apa yang diinginkan mahasiswa, sehingga mahasiswa merasa senang dalam melaksanakan perkuliahan yang diadakan di google classroom. Dalam performa google classroom, tampilan google classroom jelas dan mudah dipahami mahasiswa, mahasiswa dapat memperoleh informasi dengan mudah, materi maupun dalam mengumpulkan tugas jauh lebih mudah melalui google classroom, google google classroom dapat mempermudah mahasiswa untuk penyimpanan dokumen, materi ataupun tugas-tugas yang penting, google classroom juga memudahkan mahasiswa untuk menyelesaikan tugas, dan google classroom dapat menghemat waktu dan biaya. Bahkan faktor lain yang mempengaruhi motivasi belajar adalah disiplin belajar.

Berdasarkan hasil uji-t maka diketahui disiplin belajar $\left(\mathrm{X}_{2}\right)$ ada pengaruh yang signifikan terhadap motivasi belajar mahasiswa brothers and sisters house kota Surabaya pada masa pandemi Covid-19. Terbukti dari nilai t-hitung 7,813 > nilai t-tabel 1,989 dan nilai signifikansi $0,000<0,05$. Didukung oleh Mulyany (2014) dimana hasil penelitiannya mengemukakan terdapat pengaruh yang signifikan disiplin belajar terhadap motivasi belajar yang dibuktikan dengan signifikansi 0,000 < 0,005; Dwi, Muhsin \& Rozi (2019) dalam hasil penelitiannya menunjukkan bahwa disiplin belajar berpengaruh yang signifikan terhadap motivasi belajar, dimana terbukti dari nilai signifikansi $0,041<0,05$; Nurhuda (2016) yang menyatakan bahwa semakin tinggi tingkat disiplin yang dimiliki dosen maka akan mempengaruhi mahasiswa dalam melaksanakan pembelajaran, jika disiplin dosen semakin 
tinggi maka motivasi belajar yang dimiliki mahasiswa akan baik pula; Rahayu (2019) berdasarkan hasil penelitiannya menjelaskan bahwa ada pengaruh disiplin belajar terhadap motivasi belajar, dibuktikan pada nilai t-hitung 7,907 > t-tabel 1,974 dan sig. 0,001 < 0,05; Lutviana \& Suryani (2015) dimana membuktikan ada pengaruh yang diberikan dari disiplin belajar terhadap motivasi belajar sebesar $44,756 \%$ dan dapat dilihat juga pada nilai sig. 0,000 $<0,05$.

Dengan demikian bisa dikatakan disiplin belajar dapat memberikan pengaruh terhadap motivasi belajar mahasiswa brothers and sisters house kota Surabaya pada masa pandemi Covid-19. Dibuktikan dari ketepatan waktu mahasiswa terlibat dalam perkuliahan, tepat waktu, selalu masuk kelas untuk mengikuti kegiatan perkuliahan dan mengumpulkan tugas tepat waktu. Kesiapan dalam mengikuti perkuliahan, dimana mahasiswa membaca terlebih dahulu materi kuliah sebelum masuk kelas, mahasiswa bertukar pikiran dengan yang lainnya ketika ada tugas yang tidak diketahui solusinya bahkan akan bertanya jika materi yang diajarkan tidak diketahui. Minat mengikuti perkuliahan juga dapat diketahui dari mahasiswa belajar atas kemauan sendiri, memperhatikan materi dari dosen dan mahasiswa mendengarkan dengan baik setiap penjelasan materi yang dipaparkan. Mahasiswa juga memiliki kesungguhan dalam mengikuti perkuliahan seperti bersungguh-sungguh dalam mengerjakan tugas, mengerjakan tugas rumah sendiri, belajar setiap malam atau dalam sehari selama 1-2 jam dan mahasiswa meluangkan waktu untuk belajar di rumah.

\begin{tabular}{ccc}
\multicolumn{3}{c}{ Tabel 3. Hasil Uji-F } \\
\hline \multicolumn{3}{c}{ ANOVA $^{\mathrm{a}}$} \\
\hline Model & $\mathrm{F}$ & Sig. \\
1 & 67,322 & $0,000^{\mathrm{b}}$ \\
\hline
\end{tabular}

Berdasarkan hasil uji-F dapat diketahui bahwa penggunaan e-learning dengan google classroom $\left(\mathrm{X}_{1}\right)$ dan disiplin belajar $\left(\mathrm{X}_{2}\right)$ memberikan pengaruh yang signifikan terhadap motivasi belajar mahasiswa brothers and sisters house kota Surabaya pada masa pandemi Covid-19. Ini terbukti dari hasil uji f-hitung 67,322 > f-tabel 3,10 dan pada nilai signifikansi $0,000<0,05$. Dengan demikian didukung oleh Larasati \& Choirul (2020) dalam hasil penelitiannya mengemukakan adanya pengaruh signifikan secara simultan penggunaan smartphone dan pemanfaatan e-learning terhadap motivasi belajar siswa kelas XI OTKP SMKN 10 Surabaya sebesar 44,8\% dan dibuktikan juga dengan Fhitung sebesar 32,805 > Ftabel 3,11 dan nilai sig. sebesar 0,000 < 0,05. Penelitian dari Yulyani (2020) menjelaskan terdapat pengaruh yang signifikan positif antara media pembelajaran dengan google classroom belajar terhadap motivasi belajar selama masa pandemi Covid-19 sebesar 49,7\% sedangkan 50,3\% dipengaruhi oleh variabel lain yang tidak diteliti. Susanto, Farihen, \& Iswan (2020) dalam hasil penelitiannya ada pengaruh positif yang signifikan dari e-learning dan lingkungan kampus terhadap motivasi belajar terbukti dari nilai sig. 0,001< 0,05. Rahayu (2019) dimana hasil penelitiannya membuktikan ada pengaruh secara simultan konsep belajar dan disiplin belajar terhadap motivasi belajar sebesar 37,99\% dan dibuktikan juga dengan nilai F-hitung sebesar 40,221 > F-tabel 3,065. Penelitian Lutviana \& Suryani (2015) yang hasil penelitiannya menjelaskan bahwa terdapat pengaruh secara bersama-sama yaitu lingkungan keluarga, kesiapan belajar dan disiplin belajar terhadap motivasi belajar sebesar $67 \%$ dan nilai sig. $0,000<0,05$.

Oleh karena itu, ditarik kesimpulan ada pengaruh penggunaan e-learning dengan google classroom dan disiplin belajar terhadap motivasi belajar mahasiswa brothers and sisters house kota Surabaya pada masa pandemi Covid-19. Hal ini dapat dilihat pada konsentrasi mahasiswa dimana mahasiswa memahami instruksi yang diberikan oleh dosen, konsentrasi terhadap bahan atau materi ajar yang diberikan oleh dosen, mahasiswa mencatat 
materi ketika pembelajaran sedang berlangsung, dan mahasiswa taat pada aturan yang ada dari dosen ketika pembelajaran. Rasa ingin tahu mahasiswa dapat diketahui dari mahasiswa yang akan bertanya apabila terdapat materi yang belum bisa dipahami, mahasiswa bertanya kepada dosen apabila mengalami kesulitan dari materi yang telah dipaparkan, dan tertarik terhadap bahan atau materi yang disampaikan oleh dosen. Semangat di mana mahasiswa akan menjawab atau mengerjakan tugas yang telah diberikan dari dosen, selalu semangat dalam mengikuti perkuliahan dan aktif bertanya dalam kegiatan perkuliahan. Kesiapan mahasiswa yang diketahui dari mahasiswa selalu siap untuk menjawab ataupun mengerjakan tugas dari dosen, mempersiapkan perlengkapan belajar sebelum kelas dimulai dan mahasiswa selalu membaca buku referensi atau buku literatur yang digunakan dosen dalam perkuliahan. Antusias atau dorongan pantang menyerah dari mahasiswa yang selalu antusias agar tugas yang telah dikerjakan mendapatkan nilai sebagus mungkin, antusias untuk mengerjakan tugas dengan baik, dan mahasiswa antusias untuk menyelesaikan tugas.

\section{Kesimpulan}

Kesimpulan yang diperoleh dalam penelitian ini antara lain adalah: 1) terdapat pengaruh yang signifikan penggunaan e-learning dengan google classroom terhadap motivasi belajar mahasiswa brothers and sisters house kota Surabaya pada masa pandemi Covid-19 yang dibuktikan dari hasil uji t-hitung 2,343>t-tabel 1,898 dan nilai sig. 0,021<0,05 yang artinya hipotesis pertama diterima; 2) terdapat pengaruh yang signifikan disiplin belajar terhadap motivasi belajar mahasiswa brothers and sisters house kota surabaya pada masa pandemi Covid-19 yang dibuktikan dari hasil uji t-hitung 7,813>t-tabel 1,989 dan nilai sig. 0,000<0,05 yang artinya hipotesis kedua diterima; 3) terdapat pengaruh yang signifikan penggunaan $e$ learning dengan google classroom dan disiplin belajar terhadap motivasi belajar mahasiswa brothers and sisters house kota Surabaya pada masa pandemi Covid-19 yang dibuktikan dari hasil uji F-hitung 67,322>T-tabel 3,10 dan nilai sig. 0,000 $<0,05$ yang artinya hipotesis ketiga diterima.

\section{Saran}

Saran yang dapat disampaikan berdasarkan hasil penelitian ini, yaitu: 1) dengan adanya penggunaan e-learning dengan google classroom, dosen diharapkan mampu merangsang mahasiswa dengan berbagai model atau metode pembelajaran yang ada, seperti pemberian dan pengumpulan tugas yang tersistem, sehingga dalam melaksanakan pembelajaran mahasiswa tidak merasa bosan dan jenuh selama mengikuti perkuliahan; 2) kepada peneliti berikutnya sangat dianjurkan agar menambahkan variabel lainnya dengan menggunakan populasi dan sampel selain dari mahasiswa brothers and sisters house kota Surabaya.

\section{Daftar Pustaka}

Albashtawi, A.H. \& Al Bataineh, K.B. (2020). The Effectiveness of Google Classroom among EFL Students in Jordan: An Innovative Teaching and Learning Online Platform. International Journal of Emerging Technologies in Learning. 15(11): 7888. https://doi.org/10.3991/IJET.V15I11.12865.

Cintya, A.N.D. \& Nugraha, J. (2020). Pengaruh Sarana Prasarana dan Motivasi Belajar terhadap Hasil Belajar Siswa Kelas XII Otomatisasi Tata Kelola Perkantoran di SMK Ketintang Surabaya. Jurnal Pendidikan Administrasi Perkantoran (JPAP). 9(1): 1-16.

Daniati, D., Ismanto, B., \& Luhsasi, D.I. (2020). Upaya Peningkatan Motivasi dan Hasil Belajar Mahasiswa dengan Penerapan Model Pembelajaran E-learning Berbasis Jurnal Kependidikan Vol. 7. No. 2 : Juni 2021 
Google Classroom pada Masa Pandemi Covid-19. Kependidikan: Jurnal Hasil Penelitian dan Kajian Kepustakaan di Bidang Pendidikan, Pengajaran dan Pembelajaran. 6(3): 601-608. https://doi.org/10.33394/jk.v6i3.2642.

Dwi, E., Muhsin, \& Rozi, F. (2019). Pengaruh Lingkungan Keluarga, Disiplin Belajar, Kompetensi Sosial Guru, dan Kesiapan Belajar terhadap Motivasi Belajar. Economic Education Analysis Journal. 8(1): 302-317.

Fauzan, F. \& Arifin, F. (2019). The Effectiveness of Google Classroom Media on the Students' Learning Outcomes of Madrasah Ibtidaiyah Teacher Education Department. Al Ibtida: Jurnal Pendidikan Guru MI. 6(2): 271-285. https://doi.org/10.24235/al.ibtida.snj.v6i2.5149.

Gozali, I. (2018). Aplikasi Analisis Multivariate dengan Program IBM SPSS 25. Semarang: Undip.

Kemendikbud. (2020). Panduan Penyelenggaraan Pembelajaran pada Tahun Ajaran dan Tahun Akademik Baru di Masa Pandemi Covid-19: Satuan Pendidikan di Zona Kuning, Oranye dan Merah Dilarang Melakukan Pembelajaran Tatap Muka. https://www.kemdikbud.go.id/main/files/download/d16ebb4e0e2245e, diakses pada tanggal 29 Oktober 2020.

Larasati \& Choirul, N. (2020). Pengaruh Penggunaan Smartphone dan E-learning terhadap Motivasi Belajar dalam Masa Pelatihan Kerja. Jurnal Pendidikan Manajemen Perkantoran. 5(2): 214-233. https://doi.org/10.17509/jpm.v4i2.18008.

Lutviana, L. \& Suryani, N. (2015). Pengaruh Lingkungan Keluarga, Kesiapan Belajar, dan Disiplin Belajar terhadap Motivasi Belajar Siswa Kelas XI IPS pada Mata Pelajaran Ekonomi di MA NU Raudlatul Muallimin Wedung. Economic Education Analysis Journal. 4(1): 50-57.

Mulyany, P. (2014). Pengaruh Keterampilan Mengajar Guru, Disiplin Belajar dan Sikap Siswa terhadap Motivasi Belajar Mata Diklat Bekerjasama dengan Kolega dan Pelanggan pada Siswa Kelas X Program Keahlian Administrasi Perkantoran di SMK Pl Tarcisius 1 Semarang. Economic Education Analysis Journal. 2(3): 116-123.

Murni, M., \& Pratiwi, H. (2020). Pengaruh Fraud Diamond Terhadap Perilaku Fraud Academic dengan Student Behavior Sebagai Variabel Moderating. Jurnal Kependidikan: Jurnal Hasil Penelitian Dan Kajian Kepustakaan Di Bidang Pendidikan, Pengajaran Dan Pembelajaran, 6(3), 422-432. https://doi.org/10.33394/jk.v6i3.2908

Nirfayanti, N. \& Nurbaeti, N. (2019). Pengaruh Media Pembelajaran Google Classroom dalam Pembelajaran Analisis Real terhadap Motivasi Belajar Mahasiswa. Proximal Jurnal Penelitian Matematika dan Pendidikan Matematika. 2(1): 50-59.

Novianty, R. (2019). Pengaruh Disiplin Belajar terhadap Hasil Belajar Mahasiswa pada Mata Kuliah Metodologi Penelitian. EKSPOSE: Jurnal Penelitian Hukum dan Pendidikan. 18(2): 828-840.

Nurhuda, D.Y.W. (2016). Pengaruh Disiplin Dosen terhadap Motivasi Belajar Mahasiswa di Sekolah Tinggi Ilmu Kesehatan Bakti Tunas Husada Tasikmalaya. Jurnal Kesehatan Bakti Tunas Husada. 16(1): 32-37. https://doi.org/10.36465/jkbth.v16i1.163. 
Pradana, D.B.P. \& Harimurti, R. (2017). Pengaruh Penerapan Tools Google Classroom pada Model Pembelajaran Project Based Learning terhadap Hasil Belajar Siswa. It-Edu. 2(01): 59-67.

Rahayu, F. (2019). Pengaruh Konsep Diri dan Disiplin Belajar terhadap Motivasi Belajar Peserta Didik di Sekolah Menengah Pertama Negeri 4 Palu pada Mata Pelajaran Pendidikan Agama Islam. Paedagogia: Jurnal Pendidikan. 8(2): 113-138. https://doi.org/10.24239/pdg.vol8.iss2.45.

Ridwan, T. \& Umam, A.F. (2020). Pengaruh Media Pembelajaran Google Classroom dalam Pembelajaran terhadap Motivasi Belajar Mahasiswa. Jurnal Ilmiah Indonesia. 1(1): 37-46.

Rikizaputra \& Sulastri, H. (2020). Pengaruh E-learning dengan Google Classroom terhadap Hasil dan Motivasi Belajar Biologi Siswa. Lectura: Jurnal Pendidikan. 11(1): 106118. https://doi.org/10.2183/tja.75.1_27.

Sabran \& Sabara, E. (2019). Keefektifan Google Classroom sebagai Media Pembelajaran. Prosiding Seminar Nasional Lembaga Penelitian Universitas Negeri Makasar, hlm. 122-125, Fakultas Teknik Universitas Negeri Makasar.

Sugiyono. (2019). Metode Penelitian Kuantitatif Kualitatif dan R\&D. Bandung: Alfabeta. Sujianto, A. E. (2009). Aplikasi Statistik dengan SPSS 16.0. Jakarta: PT. Prestasi Pustaka.

Susanto, A., Farihen, \& Iswan. (2020). The Effect of Self-Regulated and Disciplined Learning on Students' Achievements. Advances in Health Sciences Research. 27(3): 123-126. https://doi.org/10.2991/ahsr.k.200723.030.

Trust. (2020). The Real Ultimate Student. trust.or.id, diakses pada tanggal 29 Oktober 2020.

Wahyono, E. (2020). Kapan Sebenarnya Corona Pertama Kali Masuk RI? https://news.detik.com/berita/d-4991485/kapan-sebenarnya-corona-pertama-kalimasuk-ri/3, diakses pada tanggal 29 Oktober 2020.

Wati, A.K. \& Muhsin. (2019). Pengaruh Minat Belajar, Motivasi Belajar, Lingkungan Keluarga, dan Lingkungan Sekolah terhadap Kesulitan Belajar. Economic Education Analysis Journal. 8(2): 797-813. https://doi.org/10.15294/eeaj.v8i2.31517.

Yulyani, R.D. (2020). Pengaruh Media Pembelajaran Google Classroom, Fasilitas Pembelajaran dan Minat Belajar Mahasiswa terhadap Motivasi Belajar Daring Selama Pandemi Covid-19. Ed-Humanistics. 5(2): 703-714.

Yussi, Syaad, \& Purnomo. (2016). The Contribution of Vocational Students' Learning Discipline, Motivation and Learning Results. International Journal of Environmental \& Science Education. 12(5): 965-970. 